\title{
Pengaruh Perceived Behavioral Control terhadap Intensi Mengurangi Waktu Penggunaan Instagram pada Mahasiswa Adiksi
}

\author{
Nadia Ayu Safira ${ }^{*}$, Fanni Putri Diantina \\ Prodi Psikologi, Fakultas Psikologi, Universitas Islam Bandung, Indonesia. \\ *ayusafiranadia@gmail.com, fanni.putridiantina@unisba.ac.id
}

\begin{abstract}
Since the emergence of Covid-19 pandemic there has been an increase of time in using social media, one of which is the use of Instagram. Spending a lot of time using Instagram has a negative impact on college students' academic performance and mental health. College students in Bandung show a high tendency of addiction to social media, one of which is Instagram. Previous studies have shown that there is significant effect of perceived behavioral control on the intention of using social networking sites. To reduce the impact of Instagram addiction, this study aims to find out how much influence perceived behavioral control has on the intention to reduce Instagram usage time in addicted college students at the Bandung. Convenience sampling were conducted to reach 237 students who are addicted to Instagram at universities in Bandung. This study uses a quantitative approach with simple regression analysis. The measuring instrument used are Bergen Social Media Addiction Scale and the construction of perceived behavioral control and intention scales which compiled by researchers based on the concept from Ajzen and Francis. The results showed that perceived behavioral control had a significant effect on the intention to reduce Instagram usage time (Kd: $32.6 \%$, Sig .000).
\end{abstract}

Keywords: Perceived behavioral control, intention, time reduction, Instagram addiction

\begin{abstract}
Abstrak. Semenjak pandemi Covid-19 terjadi peningkatan penggunaan waktu dalam menggunakan media sosial, salah satunya penggunaan Instagram. Menghabiskan waktu yang banyak menggunakan Instagram ini berdampak buruk terhadap performa akademik dan kesehatan mental mahasiswa/i. Mahasiswa/i di Bandung menunjukkan kecenderungan tinggi adiksi media sosial, salah satu media sosial yaitu Instagram. Penelitian sebelumnya menunjukkan terdapat pengaruh perceived behavioral control terhadap intesi penggunaan social networking sites. Untuk mengurangi dampak perilaku adiksi Instagram, maka penelitian ini bertujuan untuk mengetahui seberapa besar pengaruh perceived behavioral control terhadap intensi mengurangi waktu penggunaan Instagram pada mahasiswa adiksi di Perguruan Tinggi Bandung. Teknik convenience sampling digunakan untuk menjaring 237 mahasiswa yang adiksi Instagram di Perguruan Tinggi Bandung. Penelitian ini menggunakan pendekatan kuantitatif dengan analisis regresi sederhana. Alat ukur yang digunakan yaitu Bergen Social Media Addiction Scale dan konstruksi skala perceived behavioral control dan intensi yang disusun peneliti berdasarkan konsep dari Ajzen dan Francis. Hasil penelitian menunjukkan perceived behavioral control berpengaruh signifikan terhadap intensi mengurangi waktu penggunaan Instagram (Kd: $32,6 \%$, Sig .000).
\end{abstract}

Kata Kunci: Perceived behavioral control, intensi, pengurangan waktu, perilaku adiksi Instagram 


\section{A. Pendahuluan}

Semenjak pandemi Covid-19, di Indonesia terjadi peningkatan durasi online sebesar 52\%, penggunaan Internet sebesar 79,95\%, dan penggunaan Internet lebih dari 11 jam sebesar $40,3 \%$, terjadinya peningkatan penggunaan Intenet ini menyebabkan prevalensi perilaku adiksi sebesar $14,4 \%$ (Siste et al., 2020). Salah satu motif utama dalam menggunakan Internet ini yaitu untuk mengakses media sosial (Siste et al., 2020). Data terbaru Hootsuite (2021) menunjukkan rata-rata waktu penggunaan media sosial di Indonesia (3 jam 14 menit) lebih tinggi dibandingkan penggunaan secara global (2 jam 25 menit).

Salah satu jenis media sosial yang menjadi sorotan penting bagi para peneliti yaitu Social Networking Sites (SNS), hal ini karena beberapa tahun terakhir terjadi peningkatan waktu penggunaan SNS yang mengakibatkan masalah serius yaitu perilaku adiksi SNS (The Nielson Company, 2010; Kuss \& Griffiths, 2017). Perilaku adiksi SNS merupakan ketidakmampuan individu dalam mengendalikan waktu dalam menggunakan SNS sehingga berdampak buruk pada pendidikan/pekerjaan, hubungan interpersonal, kesehatan mental, serta well-being (Andreassen \& Pallessen, 2014). Perilaku adiksi SNS ini termasuk ke dalam adiksi perilaku (behavioral addiction) yang menunjukkan gejala serta dampak sama bahayanya dengan perilaku adiksi zat (Ho et al., 2017; Andreassen, 2015; APA, 2013; Kuss \& Griffiths, 2011).

Instagram merupakan salah satu platform Social Networking Sites (SNS) yang diminati banyak orang karena tersedianya fitur yang canggih dan beragam (Kim et al., 2017). Instagram merupakan platform untuk membagikan aktivitas sehari-hari melalui media foto dan video secara real time (Kim et al., 2017). Kecanggihan yang diberikan Instagram ini mendorong penggunanya untuk terus mengakses Instagram (Balakrishnan \& Griffiths, 2017b; Mateo, 2014). Indonesia sendiri termasuk ke dalam empat besar negara pengguna Instagram tertinggi se-dunia (Hootsuite et al., 2021). Lebih lanjut, semenjak pandemi Covid-19, waktu penggunaan Instagram secara global meningkat sebesar $13,8 \%$, padahal sebelumnya hanya diperkirakan terjadi peningkatan sebesar 1,3\% (eMarketer, 2020).

Peningkatan waktu dalam menggunakan Instagram menjadi masalah yang penting karena waktu yang digunakan untuk mengakses Instagram berpengaruh signifikan terhadap perilaku adiksi Instagram (Kircaburun \& Griffiths, 2019). Berdasarkan data Napoleoncat.com (2021) menunjukkan pengguna Instagram di Indonesia di dominasi oleh kelompok usia 18-24 tahun (30 juta pengguna), jika dilihat dari kelompok usia maka 18-24 tahun berada pada pendidikan mahasiswa. Terdapat penelitian terdahulu yang menunjukkan bahwa mahasiswa di Bandung sebesar 55,9\% mengalami kecenderungan tinggi perilaku adiksi media sosial, salah satu media sosial yaitu Instagram (Sumaryanti et al., 2019). Hal ini menjadi masalah penting karena perilaku adiksi Instagram dapat berdampak buruk terhadap performa akademik serta kesehatan mental mahasiswa (Foroughi et al., 2021; Ponnusamy, 2019). Sejalan dengan hasil wawancara mendalam kepada 15 mahasiswa di Perguruan Tinggi Bandung yaitu meskipun Instagram dapat digunakan untuk mendapatkan hiburan, namun mengakses Instagram dalam jumlah waktu yang banyak mengakibatkan tugas terabaikan, waktu tidur terganggu, cemas, tidak percaya diri, dan tidak puas dengan kehidupannya.

Mahasiswa berusia 18-24 tahun ini termasuk ke dalam tahap emerging adulthood yang seharusnya menggunakan waktunya untuk mengeksplor, membuat rencana, dan melakukan kegiatan yang mendukung masa depannya (Arnett, 2007). Apabila mahasiswa mengalami perilaku adiksi Instagram, maka akan mengganggu tugas perkembangan yang harus penuhi. Santrock (2010) menyatakan bahwa strategi menjadi mahasiswa yang sukses yaitu dengan membatasi penggunaan SNS, dalam hal ini adalah Instagram.

Oleh karena itu, dengan banyaknya dampak negatif dari perilaku adiksi Instagram, maka mahasiswa yang adiksi perlu merubah pola penggunaannya yaitu dengan mengurangi waktu penggunaan Instagram, hal ini karena perilaku adiksi Instagram ditandai dengan menghabiskan waktu yang banyak dalam mengaksesnya (Griffiths et al., 2014; Andreassen \& Palessen, 2014; Kircaburun \& Griffiths, 2019). Salah satu kerangka teori yang dapat menjelaskan faktor yang mendukung untuk mengurangi wakti penggunakan Instagram yaitu Theory of Planned Behavior (TPB), karena perilaku dalam menggunakan Social Networking 
Sites dipengaruhi langsung oleh intensi berdasarkan model TPB (Kim et al., 2011; Lin \& Lu, 2011). Ajzen (2020) juga mengemukakan bahwa kerangka Theory of Planned Behavior dapat menjelaskan segala perilaku dalam menggunakan teknologi.

Menurut Ajzen (1991), intensi merupakan faktor-faktor motivasional yang menghasilkan keputusan individu untuk melakukan suatu perilaku, intensi ini dibentuk oleh tiga determinan yaitu attitude toward behavior, subjective norm, dan perceived behavioral control). Attitude toward behavior menggambarkan penilaian positif atau negatif individu terhadap suatu perilaku yang (Ajzen, 2005). Kedua, subjective norm menggambarkan harapan significant others terhadap suatu perilaku tertentu (Ajzen, 2005). Ketiga, perceived behavioral control menggambarkan persepsi seberapa mampu individu melakukan serta mengendalikan perilaku tertentu (Ajzen, 2005).

Ajzen (1991;2005) mengemukakan bahwa perceived behavioral control (PBC) merupakan determinan paling penting dalam membentuk intensi, karena jika individu yakin terhadap kemampuannya untuk mengendalikan suatu perilaku maka cenderung memiliki niat yang kuat untuk melakukannya. Kemudian, keunikkan PBC dibandingkan dengan determinan lain yaitu dapat langsung mempengaruhi individu melakukan suatu perilaku tanpa melalui intensi (Ajzen, 1991). Individu yang memiliki PBC yang kuat cenderung lebih tekun melakukan suatu perilaku dibandingkan dengan individu yang tidak memiliki keyakinan terhadap kemampuannya. PBC juga dipengaruhi oleh adanya sumber daya dan besarnya kesempatan yang dimiliki individu untuk melakukan perilaku tertentu.

Terdapat keterkaitan antara konsep intensi serta perilaku adiksi, karena perilaku adiksi dapat dijelaskan berdasarkan motivasi individu yang melakukan perilaku terhadap objek adiksi secara berlebihan (Brown, 1993). Sejalan dengan konsep intensi yang menggambarkan motivasi individu melakukan perilaku tertentu (Ajzen, 1991). Selanjutnya, menurut Griffiths e al., (2005) salah satu faktor penting pembentuk perilaku adiksi yaitu kontrol individu, hal ini sesuai dengan konsep perceived behavioral control sebagai faktor pembentuk intensi individu dalam melakukan suatu perilaku.

Penelitian sebelumnya menunjukkan bahwa PBC berhubungan negatif signifikan terhadap perilaku adiksi SNS pada orang dewasa, karena ketika memiliki keyakikan dapat mengendalikan penggunaan SNS maka tidak menunjukkan kecenderungan untuk adiksi SNS (Ho et al., 2017). Selanjutnya, pada penelitian Kim et al., (2016) menunjukkan bahwa PBC berpengaruh signifikan terhadap intensi mengunggah selfie di Instagram, ketika individu memiliki keyakinan kuat terhadap kemampuan dan kontrol dalam mengunggah selfie, maka cenderung memiliki niat yang kuat untuk menggunggah selfie di Instagram. Kemudian, Baker dan White (2010) pun menunjukkan bahwa PBC berpengaruh signifikan terhadap intensi menggunakan SNS dengan waktu yang banyak. Namun demikian, pada Pelling dan White (2009), PBC tidak berpengaruh signifikan terhadap intensi menggunakan SNS.

Berdasarkan masalah serta kesenjangan yang ditemukan, maka peneliti tertarik untuk melakukan penelitian yang berjudul "Pengaruh Perceived Behavioral Control terhadap intensi mengurangi waktu penggunaan Instagram pada Mahasiswa Adiksi". Tujuan penelitian ini yaitu diantaranya, pertama, untuk mengetahui gambaran perceived behavioral control mahasiswa yang adiksi Instagram di Bandung dalam mengurangi waktu penggunaan Instagram. Kedua, untuk mengetahui gambaran intensi mahasiswa yang adiksi Instagram di Bandung untu mengurangi waktu penggunaan Instagram. Ketiga, untuk memperoleh bukti empiris terkait pengaruh perceived behavioral control terhadap intensi mengurangi waktu penggunaan Instagram.

\section{B. Metodologi Penelitian}

Variabel pada penelitian ini yaitu determinan perceived behavioral control (variabel X) dan intensi (variabel Y) berdasarkan konsep Theory of Planned Behavior (Ajzen, 1991; 2005; 2006). Theory of Planned Behavior adalah model psikologi sosial yang dapat menjelaskan perilaku individu berdasarkan intensi beserta determinan pembentuknya (Ajzen, 1991). PBC menggambarkan seberapa besar keyakinan individu terhadap kemampuan diri dalam 
melakukan suatu perilaku serta keyakinan dalam mengendalikan perilaku tersebut (Ajzen, 2006). Sedangkan, intensi menggambarkan seberapa besar individu bersedia mencoba dan berencana melakukan suatu perilaku (Ajzen, 1991).

Pengambilan data dilakukan secara online menggunakan google form. Teknik convenience sampling digunakan untuk menjaring sampel penelitian sebanyak 237 mahasiswa berusia 18-24 tahun di Perguruan Tinggi Bandung yang terkategori mengalami perilaku adiksi Instagram. Konsep yang digunakan untuk menjaring mahasiswa yang adiksi Instagram yaitu teori perilaku adiksi Social Networking Sites (Griffiths et al., 2014), gejala perilaku adiksi Instagram diantaranya salience, mood modification, tolerance, withdrawal, conflict, dan relapse. Alat ukur yang digunakan untuk menjaring mahasiswa yang adiksi yaitu Bergen Social Adiction Scale (Andreassen et al., 2016) yang telah diadaptasi oleh Sumaryanti et al., (2019). Individu terkategori adiksi Instagram jika menunjukkan skor $>18$ atau memilih pilihan jawaban 3 atau lebih minimal pada empat dari enam item (Banyai et al., 2017; Hou et al., 2019).

Sedangkan, untuk mendapatkan data terkait perceived behavioral control dan intensi menggunakan alat ukur yang disusun peneliti berdasarkan prosedur standar alat ukur TPB oleh Francis (2004) dan Ajzen (2006), serta telah dilakukan expert judgement. Penelitian ini menggunakan desain kausalitas dengan metode kuantitatif. Teknik analisis yang digunakan yaitu analisis regresi sederhana yang terdiri dari uji $\mathrm{F}$ dan koefisien determinasi.

\section{Hasil dan Pembahasan}

Distribusi Frekuensi Perceived Behavioral Control Mengurangi Waktu Penggunaan Instagram pada Mahasiswa Adiksi di Bandung

Tabel 1. Distribusi Frekuensi Perceived Behavioral Control

\begin{tabular}{lll}
\hline $\begin{array}{l}\text { Kategori Perceived } \\
\text { Behavioral Control }\end{array}$ & Frekuensi & $\%$ \\
\hline Lemah & 76 & $32.1 \%$ \\
Kuat & 161 & $67.9 \%$ \\
\hline Total & 237 & $100 \%$
\end{tabular}

Berdasarkan tabel 3.1 di atas menunjukkan bahwa dari 237 mahasiswa yang adiksi Instagram di Bandung, mayoritas memiliki perceived behavioral control yang kuat (67.9\%). Artinya, mahasiswa yang adiksi Instagram di Bandung cenderung memiliki keyakinan kuat terhadap kemampuan diri untuk mampu mengendalikan perilaku mengurangi waktu penggunaan Instagram.

\section{Distribusi Frekuensi Intensi Mengurangi Waktu Penggunaan Instagram pada Mahasiswa Adiksi di Bandung}

Tabel 2. Distribusi Frekuensi Intensi

\begin{tabular}{lll}
\hline Kategori Intensi & Frekuensi & $\%$ \\
\hline Lemah & 83 & $35 \%$ \\
Kuat & 154 & $65 \%$ \\
\hline Total & 237 & $100 \%$ \\
\hline
\end{tabular}

Berdasarkan tabel 3.2 di atas menunjukkan bahwa dari 237 mahasiswa yang adiksi 
Instagram di Bandung, mayoritas memiliki intensi yang kuat untuk mengurangi waktu penggunaan Instagram (65\%). Artinya, mahasiswa yang adiksi Instagram di Bandung cenderung bersedia dan berencana untuk mengurangi waktu penggunaan Instagram.

\section{Pengaruh Perceived Behavioral Control Terhadap Intensi Mengurangi Waktu Penggunaan Instagram pada Mahasiswa Adiksi di Bandung}

Tabel 3. Pengaruh Perceived Behavioral Control Terhadap Intensi Mengurangi Waktu Penggunaan Instagram

\begin{tabular}{lrll}
\hline Variabel & $\begin{array}{l}\text { Nilai } \\
\text { Signifi } \\
\text { kansi }\end{array}$ & $\begin{array}{l}\text { Keputu } \\
\text { san }\end{array}$ & $\begin{array}{l}\text { Koefisien } \\
\text { Determin } \\
\text { asi }\end{array}$ \\
\hline $\begin{array}{l}\text { Perceived } \\
\text { Behavioral }\end{array}$ & .000 & $\begin{array}{l}\mathrm{H}_{0} \\
\text { ditolak }\end{array}$ & $32.6 \%$ \\
$\begin{array}{l}\text { Control } \\
\text { dan Intensi }\end{array}$ & & & \\
\hline
\end{tabular}

Berdasarkan hasil perhitungan pada tabel 3.3 menunjukkan nilai signifikansi variabel perceived behavioral control (PBC) terhadap intensi yaitu sebesar .000. Pengujian dilakukan dengan membandingkan nilai signifikansi dengan nilai $\alpha=.05$, karena nilai signifikan .000 $<.05$, maka $\mathrm{H}_{0}$ ditolak. Artinya, $\mathrm{PBC}$ memberikan pengaruh yang signifikan terhadap intensi mengurangi waktu penggunaan Instagram.

Selanjutnya, nilai koefisien determinasi yang didapatkan sebesar $32.6 \%$. Hal ini menjelaskan bahwa perceived behavioral control memberikan pengaruh sebesar $32.6 \%$ terhadap perubahan variabel intensi mengurangi waktu penggunaan Instagram. Sedangkan, sisanya sebesar $67.4 \%$ dipengaruhi oleh faktor-faktor lain yang tidak diteliti.

Hasil penelitian ini sesuai dengan meta-analysis yang dilakukan oleh Ajzen (2005) bahwa PBC menunjukkan koefisen regresi sebesar .07 sampai .66 dalam mempengaruhi intensi melakukan berbagai perilaku. PBC menggambarkan keyakinan individu terhadap kemampuannya untuk menguasai suatu perilaku (Ajzen, 1991; 2005). Dengan demikian, hasil penelitian ini menunjukkan bahwa apabila mahasiswa yang adiksi memiliki keyakinan kuat terhadap kemampuannya untuk mengurangi waktu penggunaan Instagram, maka semakin kuat intensi untuk melakukan pengurangan waktu menggunakan Instagram.

Sejalan dengan Caplan (2010), LaRose et al., (2010), dan Ho et al., (2017) yang menyatakan bahwa apabila individu memiliki keyakinan diri terhadap kemampuannya untuk mengontrol dan menguasai penggunaan Social Networking Sites, maka cenderung tidak mengarahkan pada perilaku adiksi atau penggunaan media bermasalah. Mahasiswa adiksi Instagram pada penelitian ini juga mayoritas memiliki keyakinan kuat terhadap kemampuannya untuk mengurangi waktu penggunaan Instagram (67.9\%).

PBC juga dibentuk oleh adanya kesempatan (aksesibilitas), fasilitas, dan upaya individu dalam melakukan suatu perilaku (Ajzen, 1991). Subjek pada penelitian ini berada pada tahap usia emerging adulthood, individu pada tahap ini biasanya udah berpikir dan berencana mengenai masa depan, salah satunya dengan memenuhi tanggung jawab akademik yang akan bermanfaat pada waktu mendatang (Arnett, 2007; Santrock, 2016). Hasil data kuesioner menunjukkan, dengan banyaknya tugas kuliah yang harus dikerjakan dapat meningkatkan keyakinan mahasiswa yang adiksi untuk dapat mengurangi waktu penggunaan Instagram. Oleh karena itu, meningkatnya beban akademik di perguruan tinggi menjadi kesempatan besar mahasiswa yang adiksi untuk mengurangi waktu penggunaan Instagram.

Selanjutnya, PBC juga dibentuk oleh keyakinan diri (self efficacy) yang dipengaruhi oleh persiapan, pola pikir, serta rintangan yang akan dihadapi untuk melakukan suatu perilaku (Ajzen, 1991). Hasil data kuesioner menunjukkan bahwa dengan mengakses Instagram dengan waktu yang banyak, sebagian besar mahasiswa yang adiksi memiliki perencanaan dan persiapan untuk mengurangi penggunaannya. Subjek pada penelitian ini mayoritas berencana akan menonaktifkan Instagram sementara, melakukan kegiatan yang lebih produktif, serta 
bersosialisasi langsung dengan sekitar.

Apabila mahasiswa yang adiksi memiliki keyakinan, upaya, dan kesempatan besar untuk mengurangi waktu penggunaan Instagram, maka semakin tinggi niat mengurangi waktu penggunaannya (Ajzen, 1991). Dengan berpengaruhnya perceived behavioral control terhadap intensi, maka dapat menjadi peluang besar terhadap penurunan waktu penggunaan Instagram. Hal ini karena perceived behavioral control merupakan satu-satunya determinan intensi yang dapat langsung mempengaruhi perilaku tanpa melalui intensi (Ajzen, 2005). Apabila mahasiswa yang mengalami adiksi Instagram memiliki keyakinan untuk berhasil mengurangi waktu penggunaan Instagram, maka akan cenderung lebih tekun membatasi dan mengurangi waktu menggunakan Instagram.

Intensi merupakan ukuran penentu terjadinya suatu perilaku (Ajzen, 1991). Jika dilihat pada tabel 3.2 mahasiswa yang adiksi Instagram di Bandung mayoritas memiliki niat yang kuat untuk mengurangi waktu penggunaan Instagram. Oleh karena itu, memiliki niat yang kuat untuk mengurangi waktu penggunaan Instagram ini menjadi peluang besar terhadap terjadinya pengurangan waktu penggunaan Instagram sehingga diharapkan dapat menurunkan tingkat perilaku adiksi Instagram. Mengingat waktu yang digunakan untuk mengakses Instagram berpengaruh signifikan terhadap terjadinya perilaku adiksi Instagram (Kircaburun \& Griffiths, 2019).

\section{Kesimpulan}

Berdasarkan pemaparan hasil dan pembahasan, maka simpulan pada penelitian ini yaitu.

1. Mahasiswa yang adiksi Instagram berusia 18-24 tahun di Perguruan Tinggi Bandung mayoritas memiliki perceived behavioral control yang kuat untuk mengurangi waktu penggunaan Instagram (67.9\%). Hal ini menunjukkan bahwa mahasiswa yang adiksi Instagram pada penelitian ini memiliki keyakinan kuat untuk dapat mengurangi waktu penggunaan Instagram.

2. Mahasiswa yang adiksi Instagram berusia 18-24 tahun di Perguruan Tinggi Bandung mayoritas memiliki intensi yang kuat untuk mengurangi waktu penggunaan Instagram (65\%). Hal ini menunjukkan bahwa mahasiswa yang adiksi Instagram pada penelitian ini bersedia dan berencana untuk mengurangi waktu penggunaan Instagram.

3. Perceived Behavioral Control memberikan pengaruh yang signifikan sebesar $32.6 \%$ terhadap intensi mengurangi waktu penggunaan Instagram. Artinya, semakin kuat keyakinan diri terhadap kemampuan mengurangi waktu penggunaan Instagram, rencana yang akan dilakukan, dan besarnya kesempatan untuk mengurangi waktu penggunaan Instagram mendorong mahasiswa adiksi Instagram mempunyai niat yang kuat untuk mengurangi waktu penggunaan Instagram.

\section{Acknowledge}

Peneliti berterimakasih kepada seluruh pihak yang telah terlibat dan berkontribusi sehingga penelitian ini dapat selesai tepat waktu.

\section{Daftar Pustaka}

[1] Ajzen, I. (1991). The theory of planned behavior. Organizational behavior and human decision processes, 50(2), 179-211.

[2] Ajzen, I. (2005). Attitudes, personality, and behavior. New York: McGraw-Hill Education (UK).

[3] Ajzen, I. (2006). Constructing a TPB Questionnaire: Conceptual and Methodological Considerations. September 2002 (revised January 2006).

[4] Ajzen, I. (2020). The theory of planned behavior: Frequently asked questions. Human Behavior and Emerging Technologies, 2(4), 314-324.

[5] American Psychiatric Association. (2013). Diagnostic and Statistical Manual for Mental Disorders. 5th ed. Washington, DC: American Psychiatric Association. 
[6] Andreassen, C. S. (2015). Online social network site addiction: A comprehensive review. Current Addiction Reports, 2(2), 175-184.

[7] Andreassen, C. S., Billieux, J., Griffiths, M. D., Kuss, D. J., Demetrovics, Z., Mazzoni, E., $\&$ Pallesen, S. (2016). The relationship between addictive use of social media and video games and symptoms of psychiatric disorders: A large-scale cross-sectional study. Psychology of Addictive Behaviors. https://doi.org/10.1037/adb0000160.

[8] Andreassen, C. S., \& Pallesen, S. (2014). Social network site addiction - An overview. Current Pharmaceutical Design, 20, 40534061. http://doi.org/10.2174/13816128113199990616

[9] Arnett, J. J. (2007). Emerging adulthood: What is it, and what is it good for?. Child development perspectives, 1(2), 68-73.

[10] Baker, R. K., \& White, K. M. (2010). Predicting adolescents' use of social networking sites from an extended theory of planned behaviour perspective. Computers in Human Behavior, 26(6), 1591-1597. https://doi.org/10.1016/j.chb.2010.06.006

[11] Banyai F, Zsila A, Kiraly O, Maraz A, Elekes Z, Griffiths MD, et al. (2017). Problematic Social Media Use: Results from a Large-Scale Nationally Representative Adolescent Sample. PLOS ONE. DOI: 10.1371/journal.pone.0169839

[12] Balakrishnan, J., \& Griffiths, M. D. (2017b). An exploratory study of 'selfitis' and the development of the Selfitis Behavior Scale. International Journal of Mental Health and Addiction. Advance online publication. https://doi.org/10.1007/s11469-017-9844-X

[13] Brown, R. I. F. (1993). Some contributions of the study of gambling to the study of other addictions. In W. R. Eadington, \& J. Cornelius (Eds), Gambling behavior and problem gambling. Reno, NV: University of Nevada Press.

[14] Caplan, S. E. (2010). Theory and measurement of generalized problematic Internet use : A two-step approach. Computers in Human Behavior, 26, 1089-1097. http://doi.org/10.1016/j.chb.2010.03.012

[15] Emarketer. (2020). Social Networks See Boosts in Engagement Among Users, but Not Equally. Diakses melalui https://www.emarketer.com/content/social-networks-seeboosts-in-engagement-among-users-but-not-equally pada tanggal 2 April 2021

[16] Foroughi, B., Griffiths, M. D., Iranmanesh, M., \& Salamzadeh, Y. (2021). Associations between Instagram addiction, academic performance, social anxiety, depression, and life satisfaction among university students. International Journal of Mental Health and Addiction, 1-22.

[17] Francis, J., Eccles, M., Johnston, M., Walker, A., Grimshaw, J., Foy, R., \& Bonetti, D. (2004). Theory of planned behaviour questionnaires: Manual for researchers. Newcastle: Centre for Health Services Research.

[18] Griffiths, M.D. (2005). A "components" model of addiction within a biopsychosocial framework. J. Subst, 10, 191-197. https://doi.org/10.1080/14659890500114359

[19] Griffiths MD, Kuss DJ, Demetrovics Z. (2014). Social networking addiction: an overview of preliminary findings. In: Rosenberg KP, Feder LC, editors. Behavioral addictions: criteria, evidence, and treatment.London:Academic, p.11941. https://doi.org/10.1016/B978-0-12-407724-9.00006-9

[20] Ho, S. S., Lwin, M. O., \& Lee, E. W. (2017). Till logout do us part? Comparison of factors predicting excessive social network sites use and addiction between Singaporean adolescents and adults. Computers in Human Behavior, 75, 632-642. https://doi.org/10.1016/j.chb.2017.06.002

[21] Hootsuite, We Are Social. (2021). Digital 2021: Global Overview Report. Diakses melalui https://datareportal.com/reports/digital-2021-global-overview-report pada 1 Maret 2021. 
[22] Hou, Y., Xiong, D., Jiang, T., Song, L., \& Wang, Q. (2019). Social media addiction: Its impact, mediation, and intervention. Cyberpsychology: Journal of psychosocial research on cyberspace, 13(1).

[23] Kim, B. (2011). Understanding antecedents of continuance intention in social-networking services. Cyberpsychology, Behavior, and Social Networking, 14, 199205. http://doi.org/10.1089/cyber.2010.0009

[24] Kim, E., Lee, J. A., Sung, Y., \& Choi, S. M. (2016). Predicting selfie-posting behavior on social networking sites: An extension of theory of planned behavior. Computers in Human Behavior, 62, 116-123. https://doi.org/10.1016/j.chb.2016.03.078

[25] Kim, D. H., Seely, N. K., \& Jung, J.-H. (2017). Do you prefer, Pinterest or Instagram? The role of image-sharing SNSs and self-monitoring in enhancing ad effectiveness. Computer in Human Behavior, 70, 535-543.

[26] Kurcaburun, K., \& Griffiths, M. D. (2019). Problematic Instagram use: The role of perceived feeling of presence and escapism. International Journal of Mental Health and Addiction, 17(4), 909-921.

[27] Kuss, D. J., \& Griffiths, M. D. (2011). Online social networking and addiction-a review of the psychological literature. International journal of environmental research and public health, 8(9), 3528-3552. https://doi.org/10.3390/ijerph8093528

[28] Kuss, D. J., \& Griffiths, M. D. (2017). Social networking sites and addiction: Ten lessons learned. International Journal of Environmental Research and Public Health, 14(3),311.https://doi.org/10.3390/ijerph14030311

[29] LaRose, R., Kim, J., \& Peng, W. (2010). Social networking: Addictive, compulsive, problematic, or just another media habit. In Z. Papacharissi (Ed.), A networked self: Identity, community, and culture on social network sites (pp. 59-81). New York: Routledge

[30] Lin, K. Y., \& Lu, H. P. (2011). Why people use social networking sites: An empirical study integrating network externalities and motivation theory. Computers in Human Behavior, 27, 1152-1161. http://doi.org/10.1016/j.chb.2010.12.009

[31] Mateo, A. (2014). Instagram addiction is real: Step away from the smartphones. Retrieved November 6, 2017, from http://www. self.com/story/instagram-addiction-real

[32] Napoleoncat.com. (2021). Instagram Users in Indonesia. Diakses melalui https://napoleoncat.com/stats/instagram-users-in-indonesia/2020/11 pada $23 \mathrm{Mei}$ 2021.

[33] Pelling, E. L., \& White, K. M. (2009). The theory of planned behavior applied to young people's use of social networking web sites. CyberPsychology \& Behavior, 12(6), 755759. https://doi.org/10.1089=cpb.2009.0109

[34] Ponnusamy, S., Iranmanesh, M., Foroughi, B., \& Hyun, S. S. (2020). Drivers and outcomes of Instagram Addiction: Psychological well-being as moderator. Computers in Human Behavior, 107, 106294. https://doi.org/10.1016/j.chb.2020.106294

[35] Santrock, John W. (2010). Educational Psychology. New York: McGraw-Hill Education

[36] Siste, K., Hanafi, E., Lee Thung Sen, H. C., Adrian, L. P. S., Limawan, A. P., Murtani, B. J., \& Suwartono, C. (2020). The Impact of Physical Distancing and Associated Factors Towards Internet Addiction Among Adults in Indonesia During COVID-19 Pandemic: A Nationwide Web-Based Study. Frontiers in psychiatry, 11. doi: 10.3389/fpsyt.2020.580977'

[37] Sumaryanti, I. U., Azizah, S., Diantina, F. P., \& Nawangsih, E. (2019). Personality and Social Media Addiction Among College Students. In 2nd Social and Humaniora Research Symposium (SoRes 2019) (pp. 376-379). Atlantis Press. https://dx.doi.org/10.2991/assehr.k.200225.07.

[38] The Nielsen Company. (2010). Global Audience Spends Two Hours More a Month on 
Nadia Ayu Safira, et al.

Social Networks than Last Year; The Nielsen Company: New York, NY, USA. 